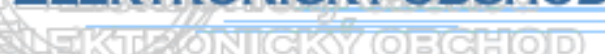

\title{
KONCEPT VYTVÁRANIA STRATÉGIE RIADENIA L'UDSKÝCH ZDROJOV V SLOVENSKEJ POŠTE, A. S.
}

\author{
Kamila Jandzíková ${ }^{1}$, Mariana Strenitzerová ${ }^{2}$
}

1. Úvod

SP, a. s. si uvedomuje, že v súčasnosti sú ovel’a dostupnejšie nové technológie ako l'udské zdroje. Uvedomuje si, že kvalitných zamestnancov na trhu práce získava len vel'mi t’ažko, alebo na nich musí vynakladat' značné finančné prostriedky. Ked' vidí, ako dlho vychováva špičkového zamestnanca, musí sa zamýšl'at' nad týmito otázkami:

- Aké požiadavky budú na našich l'udí kladené v budúcnosti?

- Aké vedomosti, schopnosti a postoje si budú musiet' osvojit?

- Aké nové potreby sa u nich objavia?

- Akým komerčným ponukám bude na trhu práce čelit?

- Čím si kvalitných zamestnancov udrží?

- Čo ich bude motivovat' $\mathrm{k}$ dosahovaniu požadovaných výkonov?

- Aké štýly vedenia l’udí a riadenia prinesú najvyššiu efektivitu?

SP, a. s. zistila, že s dôverou zamestnancov a ich lojalitou nemôže experimentovat' a improvizovat', a to ju viedlo k nutnosti začat' riadit' l'udské zdroje strategicky - cielene. Tvorba stratégie riadenia l'udských zdrojov v SP, a. s. je kl'účovým programom prípravy SP, a. s. na budúce obdobie. Hlavným poslaním úseku l'udských zdrojov je vytvorenie personálnej platformy pre trvalé zvyšovanie výkonnosti a formovanie zákaznícky orientovanej spoločnosti.

Zavedenie strategického riadenia l'udských zdrojov umožní harmonizovat' podnikovú stratégiu s ciel'mi v personálnej oblasti. Len ak stratégia riadenia l'udských zdrojov podporuje dosahovanie plánovaných firemných ciel'ov, nadobúda riadenie l'udských zdrojov plnohodnotného významu.

Podstatu navrhnutého strategického riadenia l’udských zdrojov v SP, a. s. znázorňuje obr. 1. Z obrázku vyplýva nutnost' prepojenia - integrácie stratégie riadenia l'udských zdrojov so stratégiou SP, a. s., s jej poslaním a víziou, ako aj nutnost' zaistit', aby iniciatívy manažmentu v oblasti riadenia l'udských zdrojov boli v súlade s rozhodnutiami, ktoré sú prijímané $\mathrm{v}$ iných funkčných oblastiach SP, a. s.. Kl'účovým prvkom je zabezpečit' fungovanie pojmu „súlad“ - súlad riadenia l’udských zdrojov so strategickým zameraním SP, a. s..

\footnotetext{
${ }^{1}$ Mgr. Kamila Jandzíková, Slovenská pošta, a.s., Partizánska cesta 9, 97599 Banská Bystrica, Slovenská republika tel. 00421-048-433 92 06, fax 00421-048-411 52 13, e-mail: jandzikova.kamila@slposta.sk

${ }^{2}$ doc. Ing. Mariana Strenitzerová, PhD., Žilinská Univerzita v Žiline, Fakulta prevádzky a ekonomiky dopravy a spojov, Katedra spojov, Univerzitná 1, 01026 Žilina, Slovenská republika tel. 00421-041-5133 131, fax 00421-041-5655 615, e-mail: Mariana.Strenitzerova@fpedas.uniza.sk
} 


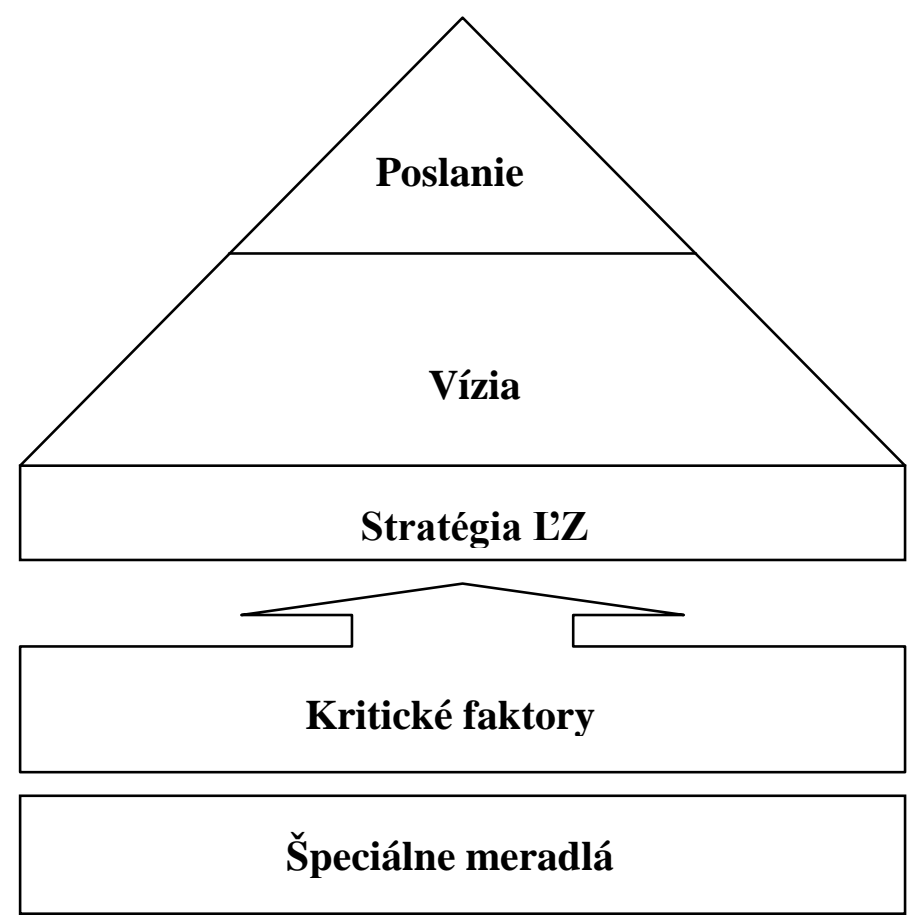

Čo sa očakáva?

Kam SP smeruje?

Ako to dosiahnut?

Čo je k tomu potrebné?

Ako máme zmerat' správnost'

Obr. 1: Podstata strategického riadenia l'udských zdrojov v SP, a. s.

\section{Stratégia riadenia l'udských zdrojov SP, a. s.}

Navrhnutá stratégia riadenia l’udských zdrojov SP, a. s. bude koncipovaná na základe analýzy súčasnej činnosti úseku l'udských zdrojov, analýzy smerovania SP, a. s., analýzy vzt’ahových polí a na základe určenia ciel'ového konceptu fungovania úseku l'udských zdrojov v dlhodobom časovom horizonte.

Pri vytváraní stratégie riadenia l'udských zdrojov je potrebné vychádzat' z:

- analýzy súčasného stavu,

- strategických ciel'ov SP, a. s. v oblasti riadenia l'udských zdrojov.

Analýza súčasného stavu

$\mathrm{Na}$ základe uskutočnenej analýzy súčasného stavu je potrebné sa v budúcom období zamerat' hlavne na:

- sústavné presadzovanie a rozvoj tých firemných hodnôt, ktoré umocňujú výkonový potenciál SP, a. S. v náročných podmienkach liberalizovaného poštového trhu a podporujú dosiahnutie vízie spoločnosti a jej ciel'ov,

- proaktívne postavenie každého zamestnanca v procesnej organizácii:

o vlastníctvo procesov (prejavuje sa vo forme žiaduceho ciel’ového správania zamestnancov ako správcov, tvorcov a inovátorov procesu tvorby hodnôt),

o sebazodpovednost' každého zamestnanca za rozvoj vlastných spôsobilostí, t.j. zvyšovanie pripravenosti k takým budúcim ciel'om a výkonom, ktoré sú definované strategickými ciel'mi rozvoja SP, a. s.

- získavanie a rozvoj takých profilov spôsobilostí pracovníkov umožňujúci budovat' celofiremné kl'účové spôsobilosti, ktoré podporia prechod spoločnosti na zákaznícky orientovanú spoločnost', 
- iniciáciu zmien a transformačných procesov na podporu naplńania strategickej orientácie spoločnosti v meniacom sa prostredí,

- zabezpečenie aktívnej podpory riadiacich štruktúr firmy pri riadení zmien a partnerstva pri realizácii projektov implementácie nových technológií a postupov,

- prehlbovanie dimenzie vodcovstva (leadership) na všetkých pozíciách a úrovniach a to predovšetkým v dvoch základných dimenziách:

o v kvantitatívnom a kvalitatívnom zdokonal'ovaní tvorby hodnôt,

o pri vedení zákazníkov (interných aj externých) k maximálnemu zhodnoteniu týchto hodnôt,

- zabezpečenie aktívnej podpory inovačnej politiky, vrátane zabezpečenia a podpory účinných nástrojov a podporných systémov inovačného rozvoja,

- zabezpečenie súčinnosti pri automatizácii procesov s dôrazom na „zabudovanie“ účinných spätných väzieb, ktoré zamestnancom umožnia riadenie vlastného výkonu v reálnom čase ako aj rozvoj vlastného spôsobilostného potenciálu (odborný a kariérový rozvoj),

- zavedenie platformy pre integrované riadenie rozvoja personálnych procesov a činností,

- trvalé zvyšovanie efektívnosti všetkých personálnych procesov a činností na platforme vnútorných i vonkajších vzt’ahových štandardov (interný a externý benchmarking),

- cielené formovanie inovatívnej výkonovej kultúry vlastníkov procesov, ktorí sú plne identifikovaní s poslaním, víziou a strategickými ciel'mi,

- riadenie a rozvíjanie znalostného kapitálu ako dôležitej dimenzie výkonu všetkých zamestnancov,

- podpora a rozvoj spôsobilosti všetkých zložiek siete spoločnosti, vrátane outsourcovaných.

Strategické ciele SP, a. s. v oblasti riadenia l’udských zdrojov

K napĺn̆aniu strategických zámerov $\mathrm{v}$ dlhodobejšom časovom horizonte je nutné definovat' strategické ciele, ktoré umožnia spoločnosti predovšetkým naplnit' jej zámery a z hl'adiska predpokladanej doby implementácie patria medzi kritické prvky alebo prvky s najväčším časovým nárokom na ich implementáciu. Na základe hodnotenia súčasného stavu a pohl'adu strategického smerovania je pre SP, a. s. dôležité zamerat' sa na napíňanie nasledujúcich ciel'ov:

- dôsledne implementovat' procesné riadenie znamenajúce predovšetkým zodpovednost' l'udí za tvorbu hodnôt, stanovenie výkonových cielov, riadenie vlastného výkonu a rozvoj spôsobilosti,

- deklarácia firemných hodnôt a jasného správania sa všetkých zamestnancov s dôrazom na sebazodpovednost', dôslednost' a integritu pri presadzovaní hodnôt,

- implementovat' systém interpretácie podnikovej stratégie do strategických ciel'ov rozvoja l'udského potenciálu spoločnosti,

- zabezpečit' formovanie kl'účových spôsobilostí firmy a systém efektívneho plánovania zdrojov,

- vytvorit' a neustále zdokonal'ovat' systém riadenia výkonu na platforme systému riadenia l'udských zdrojov a vnútorného a vonkajšieho trhu práce,

- vytvorit' systém identifikácie zamestnancov s klúčovým potenciálom a spôsobilost'ami pre spoločnost',

- zabezpečit' podporu rozvoja spôsobilosti, rozvoja kariéry a vnútorný personálny marketing (systém mimoriadnej ponuky hodnôt pre špičkové talenty a nositel'ov strategického know-how),

- zabezpečit' efektívny a plne funkčný HRIS - informačný systém pre strategické riadenie l'udských zdrojov dostupný na všetkých úrovniach riadenia spoločnosti, 
- vytvorit' a implementovat' systém podpory a riadenia inovácií (vrátane tvorby rozpočtu financovanie výskumných zámerov, experimentov, projektov a pod.),

- zabezpečit' systém na podporu riadenia znalostí.

\section{Model riadenia l'udských zdrojov a koncepcia poskytovania služieb voblasti l'udských zdrojov}

V budúcom období sa budú kritériá úspešnosti v oblasti l’udských zdrojov posúvat' od interných faktorov (napr. dodržiavanie doby vybavenia žiadosti, zníženie nákladovosti, zvýšenie spokojnosti zamestnancov) k faktorom externým (napr. zvýšenie výnosov a spokojnost' zákazníkov). Obidve oblasti vedú k novým metódam realizácie praktických opatrení v rámci l’udských zdrojov, ktoré zahŕňajú externých dodávatel'ov a zákazníkov. Zákazníci sa budú prenesenou formou viac podiel'at' na rozhodovaní o obsadzovaní pozícií, o obsahu a formách školení, o hodnotení zamestnancov a pod..

Pre odborníkov l'udských zdrojov má orientácia na zákazníka dramatický dopad a prináša mnohé dôležité otázky:

- Čomu je potrebné dnes venovat' čas?

- Kto sa v spoločnosti podiel'a na vytváraní programu l'udských zdrojov?

- Kol'ko externých zákazníkov by sa malo zapojit' do tvorby a realizácie praktických opatrení l'udských zdrojov?

- Aké typy vzt’ahov naprieč jednotlivými skupinami zamestnancov v spoločnosti bude potrebné vytvorit', aby vznikli tieto externé spojnice?

Odpovede na uvedené otázky sa v nasledujúcom období budú menit' a zamestnanec l'udských zdrojov bude stále viac trávit' čas s manažérmi - svojimi zákazníkmi. Ako náhle sa prax l'udských zdrojov presunie z oblasti orientácie na zamestnanca do oblasti orientácie na zákazníka, bude to v prospech obidvoch skupín. Zamestnanci budú vidiet', že ich práca sa zhodnocuje v podobe vyššej hodnoty pre zákazníka a budú zlepšovat' adaptabilitu tým, že budú plnit' zákaznícke potreby ako aj uspokojovat' ich očakávania.

Model a koncepcia poskytovania služieb v oblasti l'udských zdrojov sú jedným z kl'účových nástrojov vytvárania stratégie l’udských zdrojov. Výber vhodného modelu môže zásadnou mierou podporit’ úspešnost' implementácie navrhnutej stratégie.

V prípade prechodu od administratívnej k zákaznícky orientovanej službe v oblasti l'udských zdrojov prinášajúcej významné hodnoty pre manažment a vedenie spoločnosti je vhodné uplatnit' model popísaný nižšie.

V súlade s uskutočnenou analýzou súčasného stavu je za východiskový stav pre stanovenie budúceho modelu považovaná situácia, popísaná na obr. 2. Riadenie l'udských zdrojov plní predovšetkým administratívnu úlohu s vel'mi malou možnost'ou prispievania manažmentu a vedeniu firmy v oblasti stratégie a plánovania. Úsek l’udských zdrojov sa historicky zameriava na administratívu a má nedostatok času na stratégiu a plánovanie.

Snahou SP, a. s. je dosiahnut' taký stav vo vnútri spoločnosti, v ktorom by l'udské zdroje boli priamou súčast'ou hodnotového ret'azca spoločnosti, boli by manažmentom vnímané ako rovnocenný partner pri realizácii business aktivít a aktívne sa podiel'ali na tvorbe stratégie, plánovaní a napíňaní ciel’ov spoločnosti (obr. 3). Cesta k dosiahnutiu tohto ideálneho stavu je však dlhá a bez realizácie významných zmien vo vnútri organizácie, a to tak na strane poskytovatel'ov služieb v oblasti l'udských zdrojov (úsek l'udských zdrojov), ako aj na strane príjemcov týchto služieb (manažment spoločnosti), je dlhodobým náročným ciel'om. 


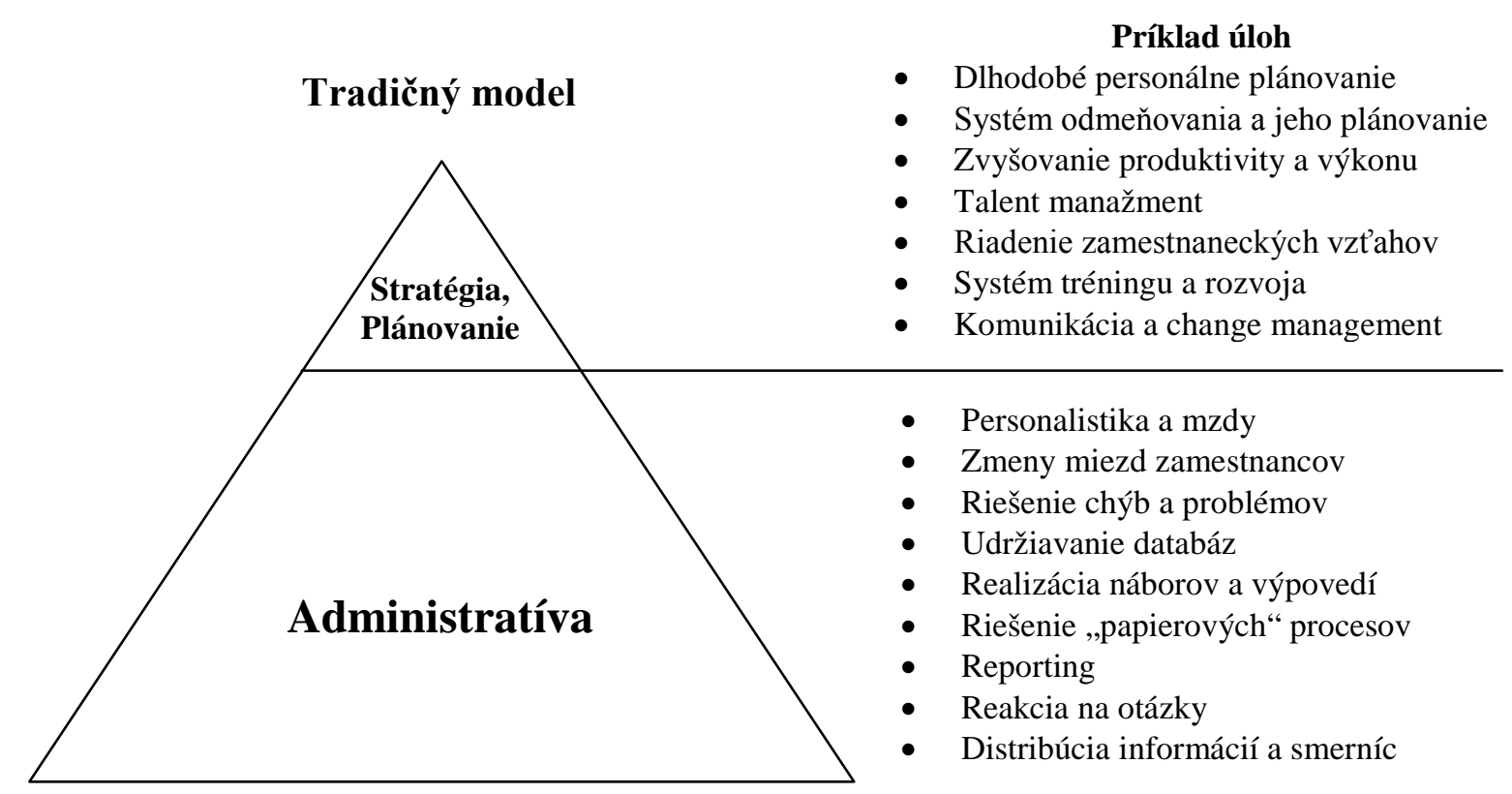

Obr. 2: Pôvodný Administratívny model riadenia l'udských zdrojov SP, a. s.

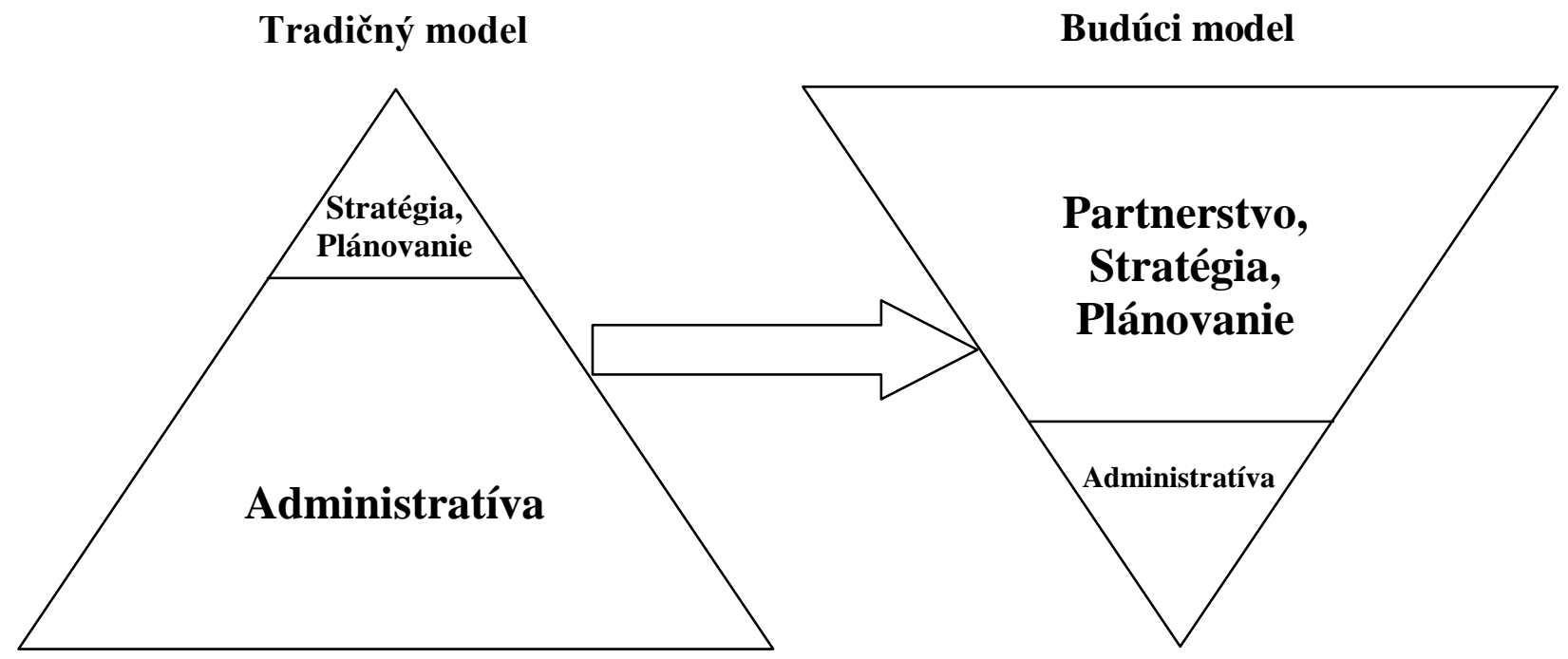

Obr. 3: Ideálny model riadenia l'udských zdrojov

$\mathrm{Na}$ základe ciel'ov SP, a. s., definovanej stratégie riadenia l'udských zdrojov a súčasného stavu procesov riadenia l'udských zdrojov je možné konkretizovat' model riadenia l'udských zdrojov (HR model) a spôsob poskytovania služieb. Z dôvodu vysokej náročnosti dosiahnutia ideálneho vyváženého modelu a spôsobu poskytovania služieb je preto nutné hl'adat' kompromis, ktorý umožní spoločnosti maximálne zefektívnit' činnosti v oblasti riadenia l'udských zdrojov, zníži administratívnu náročnost' všetkých úkonov a tým vytvorí priestor pre vytváranie pridanej hodnoty pre manažment, pre participáciu na tvorbe stratégie a business plánov takým spôsobom, že rola l'udských zdrojov začne byt' vnímaná manažmentom a vedením spoločnosti ako klúčová a na obidvoch stranách sa vytvorí tzv. business partnerský vzt’ah. 
Implementácia vhodného HR modelu a zmena role l’udských zdrojov v SP, a. s. prináša so sebou množstvo potrebných zmien, ktoré je potrebné implementovat' a overit' ich funkčnost'. Pred vlastnou implementáciou modelu je preto nutné zamerat' sa prvotne na analýzu vstupných podmienok a overit' si predovšetkým:

- Aké sú strategické ciele v oblasti l'udských zdrojov pre budúce obdobie a ako dlhé toto obdobie bude?

- Aký je stav procesov vo vnútri spoločnosti a úseku poskytujúceho činnosti/služby v oblasti l'udských zdrojov?

- Aká je úroveň vedenia a riadenia spoločnosti a aké meracie nástroje alebo nástroje spätnej väzby sú používané?

- Akým spôsobom sú v spoločnosti vedené a riadené projekty implementácie alebo zmeny?

- Aká je kultúra a úroveň komunikácie vo vnútri spoločnosti?

- Ako sú v súčasnosti vnímané služby úseku l’udských zdrojov a aká je ich úroveň?

- Aká je súčasná rola a orientácia úseku l’udských zdrojov?

Na základe týchto charakteristík je možné definovat' konkrétny HR model pre nasledujúce obdobie.

\section{Kritické faktory a špeciálne meradlá}

Na základe naznačenej schémy na obr. 1 „Podstata strategického riadenia l'udských zdrojov v SP, a. s.“ kritické faktory majú špecifikovat', čo je potrebné k naplneniu stanovených ciel'ov. V podstate ide o špecifikovanie požiadaviek na zabezpečenie zdrojov.

Požiadavky na zabezpečenie zdrojov vychádzajú z rozsahu navrhnutej stratégie l'udských zdrojov a analýzy súčasného stavu procesov a systémov riadenia l'udských zdrojov. Medzi najdôležitejšie oblasti, ktorým je potrebné venovat' pozornost', patria predovšetkým tie, ktoré sú súčast'ou kritickej cesty pri naplñaní stratégie:

- informačný systém l'udských zdrojov;

- požiadavky na l'udské zdroje v oblasti l’udských zdrojov (požiadavky na personalistov);

- požiadavky na l'udské zdroje v ostatných oblastiach spoločnosti.

V navrhnutej stratégii riadenia l'udských zdrojov SP, a. s. sú požiadavky podrobnejšie špecifikované do konkrétnych oblastí, ktorými sú:

- procesy;

- l'udia;

- technológie;

- smernice.

Špeciálne meradlá majú slúžit' ako určitá spätná väzba. Ich presné definovanie umožní spoločnosti vyhodnotit' správnost' konania pri plnení určitých strategických ciel'ov, ako aj v závere vyhodnotit' účinnost' a efektívnost' implementácie navrhnutej stratégie.

SP, a. s. ako účinný nástroj strategického riadenia navrhuje aplikovat' metodiku Balanced Scorecard (BSC). BSC je založená na jednoducho meratel'ných veličinách, ktoré zrozumitel'ným spôsobom vypovedajú o všetkom podstatnom. Pomocou vhodne zvolených ukazovatel'ov môže byt' strategicky významná výkonnost' l'udských zdrojov preložená do zrozumitel'ných podnikatel'ských termínov.

Pokial' má byt' metodika BSC uplatnená v oblasti l'udských zdrojov, je nutné stanovit' jasné strategické ciele pre oblast' l’udských zdrojov. Prvým krokom je zostavit' komplexnú stratégiu l'udských zdrojov odvodenú zo stratégie firmy. V nej musia byt' obsiahnuté dôsledky 
vyplývajúce z firemnej stratégie pre oblast' l'udských zdrojov a definované jednotlivé dielčie oblasti riadenia l'udských zdrojov. Na tejto báze sa potom stanovujú strategické ciele v každej zo štyroch dimenzií BSC: financie - zákazníci - personál - procesy/systémy. Pre tieto ciele sa potom stanovia zodpovedajúce meratel'né ukazovatele. Pre zaistenie naznačených dielčích ciel'ov sa následne zostavujú a realizujú súbory opatrení.

Nastavenie vhodných kontrolných a riadiacich mechanizmov napĺnania stratégie riadenia l’udských zdrojov je jedným zo základných faktorov schopnosti dosiahnut' vytýčené ciele. V okamžiku realizácie akéhokol'vek ciel'a je potrebné sledovat' dosahované výsledky a vývojové trendy. Jediné, s čím je možné počítat', je, že v priebehu stanoveného obdobia bude dochádzat' k zmenám, na ktoré bude nutné s rôznou intenzitou reagovat'. Rýchlost' reakcie a rozsah žiaducich zmien závisí na vel'kosti a tempe zmien v okolí a ich vplyvu na nami vytýčené ciele. $Z$ tohto dôvodu je nutné stanovit' také riadiace a kontrolné mechanizmy, ktoré nám umožnia včas a efektívne reagovat' na vzniknutú situáciu.

V strategickej oblasti je nutné vyhl'adávat' a stanovovat' také ukazovatele a metódy, ktoré nám vzhl'adom $\mathrm{k}$ implementácii stratégie umožnia na prebiehajúce zmeny reagovat' a prispôsobit' im našu stratégiu. V oblasti riadenia zdrojov sa preto v súčasnosti využíva predovšetkým strategický personálny controlling.

Implementácia strategického personálneho controllingu SP, a. s. umožní reagovat' na otázky manažmentu týkajúce sa výkonnosti l’udských zdrojov ako napr.:

- Ako l'udské zdroje prispievajú k naplńaniu strategických ciel'ov? Ako to meriame?

- Vychádzajú ciele stratégie l’udských zdrojov z ciel’ov spoločnosti? Sú identifikované kritické faktory úspechu? Sú definované merítka pre ich meranie? Vieme ako procesy riadenia l'udských zdrojov prispievajú k ciel'om spoločnosti?

- Kol'ko SP, a. s. stoja l'udské zdroje a aká je návratnost' investícii do l'udských zdrojov (HC ROI)?

- Aká je produktivita zamestnancov SP, a. s.?

- Ktoré pracovné pozície sú kl’účové pre naplnenie ciel'ov SP, a. s.?

- Má SP, a. s. ten správny počet zamestnancov? Kde by mohla ušetrit?

- Platí SP, a. s. dobre zamestnancov za výsledky ich práce?

- Platí SP, a. s. zamestnancom podl'a výkonu alebo podl'a dížky zamestnania?

- Je SP, a. s. atraktívnym zamestnávatel'om a prijíma len tých najlepších?

- Vynakladá SP, a. s. investície na tréning a rozvoj skutočne efektívne?

- Školí SP, a. s. zamestnancov v tom, čo firma potrebuje, alebo v tom, čo oni chcú?

Dôležité je taktiež efektívne riadit' procesy l'udských zdrojov s ciel'om dosiahnutia maximálnej efektivity a ich pridanej hodnoty. V súvislosti so snahou implementácie nového modelu riadenia l'udských zdrojov je potrebné zamerat' sa predovšetkým na tie oblasti, ktoré podporia jeho implementáciu a umožnia pomocou zodpovedajúcich nástrojov a meratel'ných ukazovatel'ov posunút' rolu l'udských zdrojov čo najviac do oblasti pridanej hodnoty a strategického partnerstva. V tomto zmysle je nutné implementovat' také prvky strategického personálneho controllingu, ktoré podporia rolu l'udských zdrojov, zvýšia ich pridanú hodnotu pre spoločnost' a umožnia reagovat' na otázky manažmentu ako napr.:

- Sú zamestnanci SP, a. s. skutočne nositel'mi „konkurenčnej výhody“ v poštovom sektore?

- Podávajú najlepší zamestnanci SP, a. s. skutočne najlepšie výkony?

- Podiel'a sa útvar l’udských zdrojov na zvyšovaní konkurenčnej výhody firmy?

- Aká je produktivita zamestnancov? Aké sú trendy? Aké je porovnanie s najlepšími spoločnost'ami v poštovom odvetví?

- Aký je v SP, a. s. pomer zisku na zamestnanca? Je vyšší ako v konkurenčných spoločnostiach? 
- Porovnáva SP, a. s. počet zamestnancov na jednotku predaja/produkcie s ostatnou konkurenciou?

- Nie je SP, a. s. podzamestnaná v oblastiach, kde keby pridala zamestnancov, zvýšila by sa ziskovost?

- Majú zamestnanci, ktorí sú lepšie platení, proporcionálne vyššiu produktivitu (lepšie výsledky) ako tí, ktorí sú platení priemerne?

- Stabilizuje skutočne systém benefitov zamestnancov a motivuje ich k vyšším výkonom?

- Je tréning pre SP, a. s. kritický faktor úspechu? Je korelácia medzi nákladmi na tréning a ziskom spoločnosti? Ako si stojí SP, a. s. v porovnaní s inými spoločnost'ami?

- Vedie tréning skutočne k rozdielom vo výkone? Aký je percentuálny nárast výkonu na každých napr. xxx EUR vynaložených na tréning?

- Zamestnáva SP, a. s. skutočne zamestnancov s takými kompetenciami, ktoré predstavujú pre SP, a. s. konkurenčnú výhodu?

- Je SP, a. s. vnímaná ako atraktívny zamestnávatel’?

- Je možné sledovat' zamestnancov (manažérov) s podpriemerným výkonom? Kol'ko z nich sa stalo zamestnancom s vel'mi dobrým hodnotením?

- Akým spôsobom riadenie l'udských zdrojov zlepšuje neustále svoje procesy a činnosti?

- Je možne sledovat' vplyv pracovnej spokojnosti na stabilizáciu a výkon zamestnancov?

\section{Záver}

Práca s l’udskými zdrojmi je pre úspech realizácie stratégie kl’účová. Manažéri si pod vplyvom rôznych koncepcií identifikujúcich kritické faktory úspešnosti podniku začali uvedomovat', že trvalá konkurenčná výhoda plynie zo získavania a efektívneho využívania súboru špecifických zdrojov, ktoré konkurenti nedokážu napodobnit'. Kl’účovým špecifickým zdrojom sa stávajú l'udské zdroje, ktorých rozvojom v súlade s podnikovou stratégiou, možno dosiahnut' výrazných synergických efektov.

\section{Literatúra}

[1] ARMSTRONG, M.: Personální management. Praha, Grada Publishing, 1999

[2] STRENITZEROVÁ, M.- PONIŠČIAKOVÁ, O.: Diagnostika a manažment procesov v riadení l'udských zdrojov, Monografia, Žilinská univerzita v Žiline/EDISvydavatel'stvo ŽU, 2006, ISBN 80-8070-579-8, 135 s., 67 obr., 6 tab.

[3] STRENITZEROVÁ, M.: Vytvorenie modelu procesu "Riadenie l'udských zdrojov" v podmienkach vel'kých siet'ových podnikov $=$ The composition of the process model "Human resources management" in the conditions of big network firms. In: Mladá veda, jej prínosy a perspektívy : [zborník z konferencie mladých vedeckých pracovníkov Fakulty ekonomiky a manažmentu SPU]. - Nitra: Slovenská pol'nohospodárska univerzita, 2000. - ISBN 80-7137-675-2. - S. 289-297

[4] STRENITZEROVÁ, M.: Moderný strategický prístup k inováciám. In: Pošta, Telekomunikácie a Elektronický obchod [elektronický zdroj] : elektronický odborný časopis zameraný na problematiku poštových a telekomunikačných podnikov a oblast' elektronického obchodovania. - ISSN 1336-8281. - Roč. 1, č. 4 (2006), s. 26-29 